Génét. Sél. Evol., 1984, 16 (2), 135-142

\title{
Two abnormal chromosomes found in one cell line of a mosaic cow with low fertility
}

\author{
E.R.S. ROLDAN *, María Suzanna MERANI ** \\ and Irene VON LAWZEWITSCH * \\ * Ehige-Conicet, Cátedra de Histología y Embriología, \\ Facultad de Ciencias Veterinarias, Universidad de Buenos Aires, \\ Chorroarín 280, 1427 Buenos Aires \\ ** Cátedra de Microbiología, Facultad de Medicina, \\ Universidad de Buenos Aires, 1121 Buenos Aires, Argentina
}

\begin{abstract}
Summary
A morphologically normal cow was cytogenetically investigated due to its inefficient reproduction. The female, 11 years old, had produced 3 calves with long birth to conception intervals characterized by the presence of follicular cysts. Chromosome complement was found to be $60, \mathrm{XX} / 60, \mathrm{XX}, \mathrm{t}(12 \mathrm{q} ; 15 \mathrm{q})$, inv (6). Marker chromosomes of the abnormal line were monocentric. Blood typing showed that the origin of this line was not due to chimerism associated with vascular anastomosis. Insufficient data was available to associate statistically the chromosomal abnormalities with lowered fertility.
\end{abstract}

Key words : Abnormal chromosomes, chimerism, fertility, cow.

\begin{abstract}
Résumé
Mise en évidence de deux anomalies chromosomiques dans une lignée cellulaire d'une vache à fertilité réduite
\end{abstract}

Cette étude cytogénétique concerne une vache morphologiquement normale mais à fertilité réduite. Cette femelle âgée de 11 ans, avait mis bas trois veaux espacés par de longs intervalles entre vêlage et fécondation; elle présentait également des kystes ovariens. Le caryotype de cette vache était le suivant : $60, X X / 60, X X, t(12 q ; 15 q)$, inv (6). Les chromosomes marqueurs de la lignée cellulaire anormale étaient des monocentriques. Dans cette lignée leucocytaire anormale, on a mis en évidence 2 remaniements, identifiables grâce aux mesures chromosomiques et aux bandes $\mathrm{G}$ et $\mathrm{C}$, à une translocation robertsonienne 12-15 et une inversion péricentrique du chromosome 6. L'étude des groupes sanguins a révélé que cette lignée cellulaire ne résulte pas d'un chimérisme d'anastomose vasculaire. L'information recueillie n'était pas toutefois suffisante pour établir la relation entre ces anomalies et la chute de fertilité.

Mots clés : Anomalie chromosomique, chimérisme, fertilité, vache. 


\section{Introduction}

Several structural and numerical chromosome abnormalities have been described in Bos taurus. The 1/29 translocation (GuSTAVsSON \& RocKBORN, 1964) is the only structural abnormality in which lowered fertility has unequivocally been demonstrated in heterozygous carriers (Gustavsson, 1980). It was demonstrated that 56-day nonreturn rates of translocation female carriers were lowered (Gustavsson, 1969 ; REFsDAL, 1976), daughter groups of heterozygous bulls had increased culling rates (GusTAVSSON, 1971 a) and the incidence of $1 / 29$ in a group of heifers diagnosed as repeat breeders was increased (Gustavsson, $1971 \mathrm{~b}$ ).

A definite relationship with female fertility has not been found in other structural abnormalities, namely the 2/4 (Pollock, 1972; Pollock \& Bowman, 1974), 13/21 (Harvey \& Logue, 1975), 14/24 (Di Berardino et al., 1979), 25/27 (DE Giovanni et al., 1979), 5/21 (MASUda et al., 1980), and 7/12 (HANADA et al., 1981).

In a cytogenetic survey of females with disturbed fertility, a cow with an abnormal complement was found. The karyologic study is described here.

\section{Material and methods}

One single-born, morphologically normal Holstein-Friesian cow was submitted to cytogenetic analysis due to its inefficient reproduction. The female was eleven years old and has produced three calves, with long birth to conception intervals. The post-partum periods were characterized by the presence of follicular cysts, and high milk production (mean $=7,800 \mathrm{~kg}$ ). Cysts were treated after the first and second parturitions but treatment was unsuccessful after the third one and the animal was slaughtered. Cytogenetic analysis was carried out on two different occasions according to the technique described by HALNAN (1977) with some modifications. Lymphocytes were cultured for 72 hours. Mitosis was arrested adding vinblastine sulphate (Velbe, Eli Lilly Argentina) $(1 \mu \mathrm{g} / \mathrm{ml}) 45$ minutes before sacrifice of the culture. Slides were air-dried and stained with 2 p. 100 Giemsa. G-bands were obtained by trypsin digestion (Seabright, 1971), and $\mathrm{C}$-bands with the $\mathrm{Ba}(\mathrm{OH})_{2}$ technique (Sumner, 1972). Ten abnormal metaphases were photographed and chromosomes measured. Blood typing was performed in order to investigate the possibility of a secondary chimerism due to the presence of a foetus which died in utero (STORMont, 1954).

\section{Results and discussion}

The chromosomal analysis showed the existence of two cell lines. One was normal $(60, \mathrm{XX})$ and the other presented 60 chromosomes including a Robertsonian rearrangement and a chromosome presumably having a pericentric inversion (fig. 1). The 


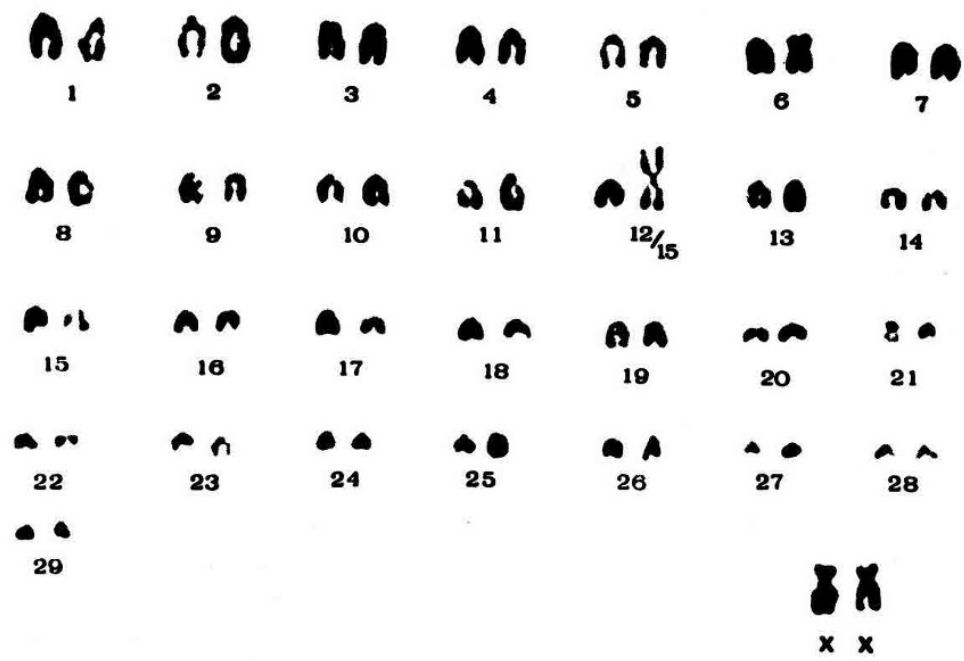

FIG. 1

Giemsa stained karyotype of the abnormal cell line of the subfertile cow. Caryotype de la lignée cellulaire anormale, coloré au Giemsa.

two marker chromosomes were present in 17 (9.35 p. 100) of 182 metaphases examined. Measurements of chromosomes allowed location of the pericentric inversion in the sixth pair and the arms of the translocated chromosome were found to be between the 10-18th and 8-13th pairs for the short and long arms respectively. The comparison of G-banded karyotypes with the Reading standard (FORD et al., 1980) showed that the short arm of the translocation corresponded to pair 15 while the long arm coincided with pair 12 (fig. 2). The chromosome with the pericentric inversion

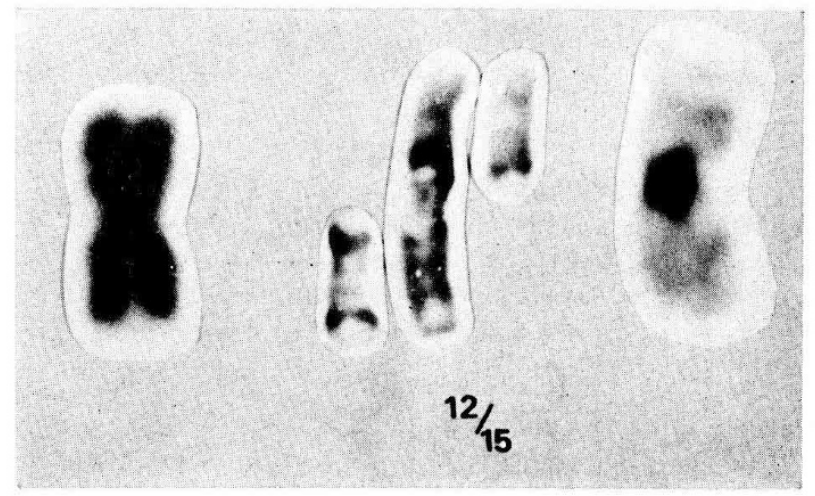

FIG. 2

Giemsa stained (left), G-bands (center), and C-bands (right) of the 12/15 translocation present in the abnormal line.

Translocation 12/15 caractérisant la lignée cellulaire anormale, coloré au Giemsa (à gauche), montrant le dessin des bandes $G$ (au centre) et des bandes $C$ (à droite). 
could not be identified by G-bands. Thus, the chromosome complement of this animal could be described as $60, \mathrm{XX} / 60, \mathrm{XX}, \mathrm{t}(12 \mathrm{q} ; 15 \mathrm{q})$, inv (6). In addition, the abnormal line contained two chromosomes No. 15 and, therefore, could be assumed as trisomic for this pair.

The treatment with $\mathrm{Ba}(\mathrm{OH})_{2}$ showed that both the translocated chromosome and the pericentric inversion presented a single block of centromeric heterochromatin, i.e. they were monocentric (fig. 2 and 3 ).

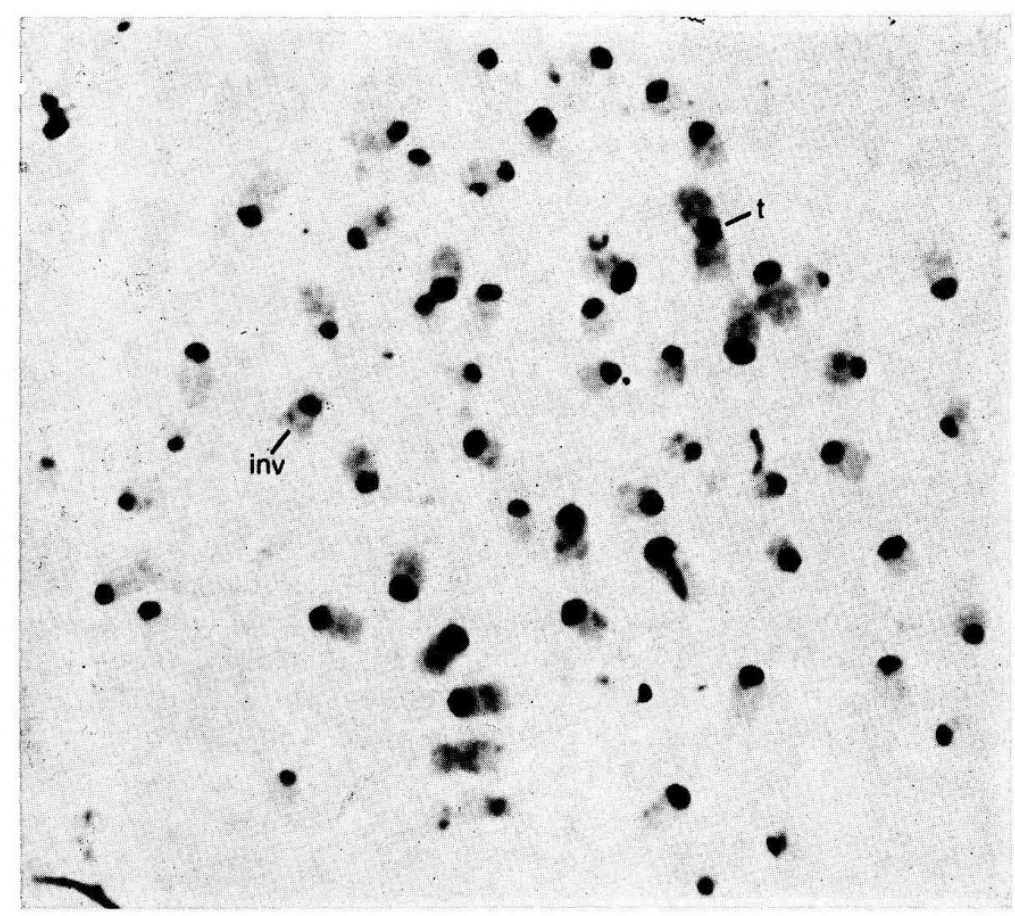

FIG. 3

$C$-bands of the abnormal line; $t=12 / 15$ translocation; inv $=$ pericentric inversion of chromosome No. 6.

Topographie des bandes $C$ de la lignée anormale; $t=$ translocation 12/15; inv $=$ inversion péricentrique du chromosome 6.

Blood typing showed complete hemolysis for the groups detected, and thus chimerism due to vascular anastomosis could be discarded. Unfortunately cytogenetic investigation of cells of different embryological origin could not be performed.

Several structural (Gustavsson et al., 1968 ; Eldridge, 1974, 1980 ; Popescu, 1977 ; Ellsworth et al., 1979 ; MASUda et al., 1980 ; Moraes et al., 1980) and numerical (RIECK et al., 1970 ; NoRBERG et al., 1976) abnormalities have been found in bovine females with or without disturbed fertility. In some cases only a few ani- 
mals with a particular abnormality have been studied so the correlation between abnormal complements and fertility was not completely established.

The presence of follicular cysts is of common occurrence in cows with high milk yield and its genetic origin has also been recognized (ROBERTs, 1971). Due to this facts and until more data related to the chromosome abnormality described here are available, it is difficult to associate this abnormal complement to the reproductive disorders found.

The origin of the abnormal cell line and the presence of two simultaneous chromosomal rearrangements are worth further considerations.

Chimerism due to the presence of a female co-twin dead in utero could be excluded because of lack of erythrocyte chimerism evidenced through blood typing (StORMONT, 1954). The difference between mosaicism and primary chimerism (McLAREN, 1976) could not be established with the methods employed. Pure autosomal trisomic embryos rarely survive until birth and are malformed (Herzog et al., 1977). It has been stated that mosaics including this condition survive more easily and even attain a normal appearance (GuSTAVSSON, 1980). The trisomy detected in pair 15 in the abnormal line of the animal described here could be an example of the latter statement.

The presence of two simultaneous chromosome abnormalities is not a frequent event (Di Berardino et al., 1979). Animals with two different centric fusions have been described among cattle (DARré et al., 1974 ; Di Berardino et al., 1979 ; MASUDA et al., 1980 ; HANAdA et al., 1981) and sheep (BRUÈre et al., 1976). Also two different and simultaneous reciprocal translocations have recently been reported in a bull (De Schepper et al., 1982) and pigs (GuSTAVSSON et al., 1982). Among cattle, all cases in which two Robertsonian translocations have been found in one animal were a combination of $1 / 29$ and a translocation not previously described, reflecting, in part, the widespread occurrence of the former. When pedigrees of these animals were analyzed it was generally found that each translocation came from different parental lines. The double reciprocal translocation found by DE SCHEPPER et al. (1982) was not traced back among the relatives. Unfortunately, as parents and calves of the cow described here were not available for study, it is not possible to speculate about the parental origin, a de novo appearance or transmission of the abnormal chromosomes found.

The dicentric chromosomes may be of more recent origin than monocentrics, according to several authors (NIEBUHR, 1972; Evans et al., 1973 ; PopesCu, 1973 ; EldRIDGe \& Balakrishnan, 1977). In view of this hypothesis the $t(12 \mathrm{q} ; 15 \mathrm{q})$ found should be assumed as an ancient one. Anyway, there is no reason to assume that a de novo translocation could not be established between the long arm of an acrocentric chromosome and a broken point opposite to the long arm of a different acrocentric chromosome (ElDRIDGE \& BALAKRISHNAN, 1977).

Pericentric inversions have been rarely found in cattle. SHORT et al. (1969) described a marker chromosome in the male line of a pair of heterosexual twins, which might represent a pericentric inversion. Popescu $(1972,1976)$ has described a pericentric inversion of chromosome number 14 which lacked C-bands. The presence of C-bands in the inversion described here could reflect the fact that in the present 
case the rearrangement could have taken place by a different mechanism than the one reported by PoPESCu (1976).

In view of these findings it would be important to study the chromosomal complements of the relatives in order to analyze the transmission and segregation of the abnormal chromosomes.

Received September 12, 1983.

Accepted November 21, 1983.

\section{Acknowledgements}

The present work was supported, in part, by IGIA, CAFPTA (grant No. 158/81) and SuBCYT (grant No. 10030 103-093). Vinblastine sulphate was gently supplied by $D^{r}$ M.L. CASÁs, Eli Lilly Argentina, Buenos Aires. The cooperation of $\mathrm{D}^{\mathbf{r}}$ L.J. DE LuCA, who referred the animal to our laboratory and María Marcela Cerutti, Laboratorio de Immunogenética, Sociedad Rural Argentina, who performed the blood typing, is gratefuly acknowledged.

\section{References}

Bruère A.N., Chapman H.M., Jaine P.M., Morris R.M., 1976. Origin and significance of centric fusions in domestic sheep. J. Hered., 67, 149-154.

Darré R., Berland H.M., QuéInNec G., 1974. Une nouvelle translocation Robertsonienne chez les bovins. Ann. Génét. Sél. Anim., 6, 297-303.

de Giovanni A.M., Succi G., Molteni L., Castiglioni M., 1979. A new autosomal translocation in "Alpine grey cattle». Ann. Génét. Sél. Anim., 11, 115-120.

de Schepper G.G., Aalbers J.G., Te Brake J.H.A., 1982. Double reciprocal translocation heterozygosity in a bull. Vet. Rec., 110, 197-199.

di Berardino D., Iannuzzi L., Ferrara L., Matasino D., 1979. A new case of Robertsonian translocation in cattle. J. Hered., 70, 436-438.

ELDRIDGE F.E., 1974. A dicentric Robertsonian translocation in a Dexter cow. J. Hered., 65, 353-355.

ELDRIDGE F.E., 1980. X-autosome translocation in cattle. 4th European Colloquium on Cytogenetics of Domestic Animals, Uppsala, 10-13 June 1980, 28-30.

EldRIDGe F.E., BalaKRIShNAN C.R., 1977. C-band variations in Robertsonian translocations in cattle. Nucleus, 20, 28-30.

Ellsworth S.M., Paul S.R., BunCh T.D., 1979. A 14/28 dicentric Robertsonian translocation in a Holstein cow. Theriogenology, 11, 165-171.

Evans H.J., Buckland R.A., Sumner A.T., 1973. Chromosome homology and heterochromatin in goat, sheep and ox studied by banding techniques. Chromosoma (Berl.), 42, 383-402.

Ford C.E., Pollock D.L., Gustavsson I. (eds.), 1980. Proceedings of the First International Conference for the Standardisation of Banded Karyotypes of Domestic Animals. Hereditas, 92, 145-162. 
Gustavsson I., 1969. Cytogenetics, distribution and phenotypic effects of a translocation in Swedish cattle. Hereditas, 63, 68-169.

Gustavsson I., 1971 a. Culling rates in daughters of sires with a translocation of the centric fusion type. Hereditas, 67, 65-73.

Gustavsson I., 1971 b. Chromosomes of repeat breeder heifers. Hereditas, 68, 331-332.

Gustavsson I., 1980. Chromosome aberrations and their influence on the reproductive performance of domestic animals. A review. Z. Tierz. Züchtgsbiol., 97, 176-195.

Gustavsson I., Fraccaro M., Tiepolo L., Lindsten J., 1968. Presumptive X-autosome translocation in a cow : Preferential inactivation of the normal $\mathrm{X}$ chromosome. Nature, Lond., 218, 183-184.

Gustavsson I., Rockborn G., 1964. Chromosome abnormality in three cases of lymphatic leukemia in cattle. Nature, Lond., 203, 990.

Gustavsson I., Settergren I., King W.A., 1982. Identification of three spontaneous reciprocal translocations in the domestic pig (personal communication).

HalNan C.R.E., 1977. An improved technique for the preparation of chromosomes from cattle blood. Res. Vet. Sci., 22, 40-43.

Hanada H., Muramatsu S., Abe T., Fukushima T., 1981. Robertsonian chromosome polymorphism found in a local herd of the Japanese Black cattle. Ann. Génét. Sél. Anim., 13, 205-211.

HARVEY M.J.A., Logue D.N., 1975. Studies on the 13/21 Robertsonian translocation in Swiss Simmental cattle. 2. Europäisches Kolloquium über Zytogenetik (Chromosomenpathologie) in Veterinärmedizin, Tierzucht und Säugetierkunde, Geissen, 29-30 September 1975, 155-161.

Herzog A., HöHN H., Rieck G.W., 1977. Survey of recent situation of chromosome pathology in different breeds of German cattle. Ann. Génét. Sél. Anim., 9, 471-491.

McLaren A., 1976. Mammalian Chimaeras. Cambridge University Press, Cambridge.

Masuda H., Shioya Y., Fukuhara R., 1980. Robertsonian translocation in Japanese Black cattle. Jap. J. Zootech. Sci., 51, 26-32.

Moraes J.C.F., Mattevi M.S., Salzano F.M., Poli J.L.E.H., Erdtmann B., 1980. A cytogenetic survey of five breeds of cattle from Brazil. J. Hered., 71, 146-148.

NiEbUHR E., 1972. Dicentric and monocentric Robertsonian translocations in man. Humangenetik, 16, 217-226.

Norberg H.S., Refsdal A.O., Garm O.N., Nes N., 1976. A case report on X-trisomy in cattle. Hereditas, 82, 69-72.

Pollock D.L., 1972. A chromosome abnormality in Friesian cattle in Great Britain. Vet. Rec., 90, 309-311.

Pollock D.L., Bowman J.C., 1974. A Robertsonian translocation in British Friesian cattle. J. Reprod. Fert., 40, 423-432.

Popescu C.P., 1972. Un cas possible d'inversion péricentrique chez les bovins. Ann. Génét. Sél. Anim., 15, 197-199.

Popescu C.P., 1973. L'hétérochromatine constitutive dans le caryotype bovin normal et anormal. Ann. Génét., 16, 183-188.

Popescu C.P., 1976. New data on pericentric inversion in cattle (Bos taurus L.). Ann. Génét. Sél. Anim., 8, 443-448.

Popescu C.P., 1977. A new type of Robertsonian translocation in cattle. J. Hered., 68, 139-142.

RefSDAL A.O., 1976. Low fertility in daughters of bulls with $1 / 29$ translocation. Acta Vet. Scand., 17, 190-195.

Rieck G.W., Höhn H., Herzog A., 1970. X-Trisomie beim Rind mit Anzeichen familiärer Disposition für Meiosestörungen. Cytogenetics, 9, 401-409.

Roberts S.J., 1971. Veterinary Obstetrics and Genital Diseases. 2nd ed., Published by the author, Ithaca N.Y. 
SEABRIGHT M., 1971. A rapid banding technique for human chromosomes. Lancet, 2, 971-972.

Short R.V., Smith J., ManN T., Evans E.P., Hallett J., Fryer A., Hamerton J.L., 1969. Cytogenetic and endocrine studies of a freemartin heifer and its bull co-twin. Cytogenetics, 8, 369-388.

Stormont C., 1954. Erythrocyte mosaicism in a heifer recorded as single-born. J. Anim. Sci., 13, 94-98.

SUMNER A.T., 1972. A simple technique for demonstrating centromeric heterochromatin. Exp. Cell. Res., 75, 304-306. 